\title{
TU/e EmonOWEN

\section{Failure of decellularized porcine small intestinal submucosa as a heart valved conduit}

\section{Citation for published version (APA):}

van Rijswijk, J. W., Talacua, H., Mulder, K., van Hout, G. P. J., Bouten, C. V. C., Gründeman, P. F., \& Kluin, J. (2020). Failure of decellularized porcine small intestinal submucosa as a heart valved conduit. Journal of Thoracic and Cardiovascular Surgery, 160(4), e201-e215. https://doi.org/10.1016/j.jtcvs.2019.09.164

\section{Document license: \\ TAVERNE}

DOI:

10.1016/j.jtcvs.2019.09.164

Document status and date:

Published: 01/10/2020

\section{Document Version:}

Publisher's PDF, also known as Version of Record (includes final page, issue and volume numbers)

\section{Please check the document version of this publication:}

- A submitted manuscript is the version of the article upon submission and before peer-review. There can be important differences between the submitted version and the official published version of record. People interested in the research are advised to contact the author for the final version of the publication, or visit the $\mathrm{DOI}$ to the publisher's website.

- The final author version and the galley proof are versions of the publication after peer review.

- The final published version features the final layout of the paper including the volume, issue and page numbers.

Link to publication

\section{General rights}

Copyright and moral rights for the publications made accessible in the public portal are retained by the authors and/or other copyright owners and it is a condition of accessing publications that users recognise and abide by the legal requirements associated with these rights.

- Users may download and print one copy of any publication from the public portal for the purpose of private study or research.

- You may not further distribute the material or use it for any profit-making activity or commercial gain

- You may freely distribute the URL identifying the publication in the public portal.

If the publication is distributed under the terms of Article 25fa of the Dutch Copyright Act, indicated by the "Taverne" license above, please follow below link for the End User Agreement:

www.tue.nl/taverne

Take down policy

If you believe that this document breaches copyright please contact us at:

openaccess@tue.nl

providing details and we will investigate your claim. 


\section{Failure of decellularized porcine small intestinal submucosa as a heart valved conduit}

Jan Willem van Rijswijk, MSc, ${ }^{\mathrm{a}, \mathrm{b}}$ Hanna Talacua, MD, PhD, ${ }^{\mathrm{a}, \mathrm{c}}$ Khadija Mulder, MSc, ${ }^{\mathrm{d}}$

Gerardus P. J. van Hout, MD, PhD, ${ }^{\mathrm{e}}$ Carlijn V. C. Bouten, $\mathrm{PhD},{ }^{\mathrm{d}, \mathrm{f}}$ Paul F. Gründeman, MD, PhD, ${ }^{\mathrm{e}}$ and Jolanda Kluin, $\mathrm{MD}, \mathrm{PhD}^{\mathrm{a}}$

\section{ABSTRACT}

Objective: Decellularized extracellular matrix made from porcine small intestinal submucosa, commercially available as CorMatrix (CorMatrix Cardiovascular, Inc, Roswell, Ga) is used off-label to reconstruct heart valves. Recently, surgeons experienced failures and words of caution were raised. The aim of this study was to evaluate decellularized porcine small intestinal submucosa as right-sided heart valved conduit in a xenogeneic animal model.

Methods: A pulmonary valve replacement was performed with custom-made valved conduits in 10 lambs and 10 sheep ( 1 month [3 lambs and 3 sheep], 3 months [3 lambs and 3 sheep], 6 months [4 lambs and 4 sheep]). Valve function was assessed after implantation and before the animal was put to death. Explanted conduits were inspected macroscopically and analyzed using immunohistochemistry and scanning electron microscopy. They also underwent mechanical testing and testing for biochemical composition.

Results: All valved conduits were successfully implanted. Five sheep and 2 lambs died due to congestive heart failure within 2 months after surgery. In the animals that died, the valve leaflets were thickened with signs of inflammation (endocarditis in 4). Five sheep and 8 lambs ( 1 month: 6 out of 6 animals, 3 months: 4 out of 6 animals, 6 months: 3 out of 8 animals) survived planned follow-up. At the time they were put to death, 5 lambs had significant pulmonary stenosis and 1 sheep showed severe regurgitation. A well-functioning valve was seen in 4 sheep and 3 lambs for up to 3 months. These leaflets showed limited signs of remodeling.

Conclusions: Fifty percent of sheep and $20 \%$ of lambs died due to valve failure before the planned follow-up period was complete. A well-functioning valve was seen in $35 \%$ of animals, albeit with limited signs of tissue remodeling at $\leq 3$ months after implantation. Further analysis is needed to understand the disturbing dichotomous outcome before clinical application can be advised. (J Thorac Cardiovasc Surg 2020;160:e201-15)

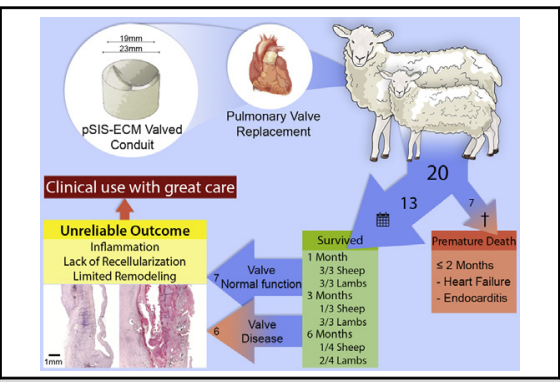

Unreliable outcome of porcine small intestinal submucosa implanted as a heart valved conduit.

\section{CENTRAL MESSAGE}

The use of CorMatrix pSIS-ECM

in heart valve surgery should be

considered with great care

because of unreliable outcomes

due to inflammatory reaction

and lack of constructive

remodeling.

\section{PERSPECTIVE}

The use of CorMatrix pSIS-ECM as heart valve repair or replacement material may be suboptimal. Further histopathological evaluations should be undertaken to better understand how CorMatrix behaves in the human cardiovascular system. Until then, the use of CorMatrix cannot be advised.

See Commentaries on pages e217, e221, and e222.

\footnotetext{
From the ${ }^{\text {a Department }}$ of Cardiothoracic Surgery, Amsterdam University Medical Center, University of Amsterdam, Amsterdam, The Netherlands; Departments of ${ }^{\mathrm{b}}$ Pathology, ${ }^{\mathrm{c}}$ Cardiothoracic Surgery, and ${ }^{\mathrm{e}}$ Experimental Cardiology, University Medical Center Utrecht, The Netherlands; and ${ }^{\mathrm{d}}$ Department of Biomedical Engineering and ${ }^{\mathrm{f} I n s t i t u t e}$ for Complex Molecular Systems, Eindhoven University of Technology, The Netherlands.

Supported by The Dutch Heart Foundation.

Received for publication Dec 18, 2018; revisions received Sept 8, 2019; accepted for publication Sept 23, 2019; available ahead of print Jan 10, 2020.
}

Address for reprints: Jolanda Kluin, MD, PhD, Department of Cardiothoracic Surgery, Amsterdam University Medical Center, B2 - 216, Meibergdreef 9, 1105 AZ Amsterdam, The Netherlands (E-mail: j.kluin@amsterdamumc.nl). $0022-5223 / \$ 36.00$

Copyright $\Subset 2020$ Published by Elsevier Inc. on behalf of The American Association for Thoracic Surgery

https://doi.org/10.1016/j.jtcvs.2019.09.164 


\section{Abbreviations and Acronyms \\ $\alpha$ SMA $=$ alpha-smooth muscle actin \\ FDA $\quad=$ Food and Drug Administration \\ pSIS-ECM $=$ decellularized extracellular matrix made from porcine small intestinal submucosa \\ PS = pulmonary stenosis \\ sGAG = sulfated glycosaminoglycan}

Heart valve disease is a common diagnosis worldwide in adult and pediatric patients. Currently used valve prostheses have resulted in enhanced survival and quality of life, but they have significant limitations, such as enhanced thromboembolic risk, requirement of lifelong anticoagulation treatment, and progressive tissue deterioration with a limited life span requiring reoperations in the case of mechanical valves and bioprostheses. ${ }^{1}$ Tissue engineering of heart valves aims at the creation of living valves with the capacity to grow, repair, and remodel. ${ }^{2,3}$ Decellularized extracellular matrix made from porcine small intestinal submucosa (pSIS-ECM) is of great interest for in situ tissue engineering of heart valves. It is presented as naturally occurring and harvestable ECM. ${ }^{4}$ In the pulmonary position, a small number of animal studies have shown tissue remodeling; however, these studies were performed in a homogeneic setting (porcine), whereas pSIS-ECM used in human patients is xenogeneic. ${ }^{5,6}$ Although not extensively and independently studied in preclinical trials, pSIS-ECM is used off-label for valve reconstructions in human beings. Recently, surgeons experienced early failures after valve reconstruction using CorMatrix (CorMatrix Cardiovascular, Inc, Roswell, Ga) and a word of caution was raised regarding the use of pSIS-ECM in heart valve repair. ${ }^{7}$ Concerned about the inconsistent clinical results of using CorMatrix in cardiac surgery, we aimed to evaluate the feasibility of pSIS-ECM as a pulmonary valve in a xenogeneic animal model.

\section{METHODS}

\section{Animals and Study Setup}

Ten female swifter sheep (weight, $62.5 \pm 8.7 \mathrm{~kg}$ and age, $3.1 \pm 2.3$ years) and 10 female swifter lambs (weight, $33.5 \pm 6.4 \mathrm{~kg}$ and age, $7.5 \pm 2.2$ months) underwent pulmonary valve replacement with a custommade valved conduit made of CorMatrix. Follow-up was 1 month $(\mathrm{n}=3$ sheep and $\mathrm{n}=3$ lambs), 3 months $(\mathrm{n}=3$ sheep and $\mathrm{n}=3$ lambs), and 6 months $(\mathrm{n}=4$ sheep and $\mathrm{n}=4$ lambs). Approval for the animal studies was obtained from the University Medical Center Utrecht Animal Care Ethics committee in agreement with the current Dutch law on animal experiments.

\section{Conduit Construction and Pulmonary Valve Replacement}

While the operation on the sheep was started (HT, JK), a second surgeon (PFG) constructed the valved conduit under sterile conditions. The constructed valved conduit is a modification of the valved conduit described by Gilbert and colleagues. ${ }^{8}$ The width of the pSIS-ECM sheet at level $\mathrm{C}$ determines the diameter of the final conduit at the level of the top of the commissures (when folded and invaginated; 19 and $23 \mathrm{~mm}$ diameter for lambs and sheep, respectively). (Figure 1, A) Next, the conduit was folded inward and 2 layers were fixed at 3 points using sutures; the inner layer forms the valve leaflets. The diameter at the proximal side (inlet $\mathrm{BB}^{\prime}$ in Figure 1, $A$ ) of the conduit is larger when compared with the diameter at the distal outlet (AA' in Figure 1, A), with the aim to enlarge coaptation area of the leaflets. Commissures were reinforced with ECM patches. The surgical procedure is further described in Appendix E1.

\section{(Immuno)histochemistry and Histologic Quantification}

After macroscopic inspection, sections were fixed in $10 \%$ formalin for at least 48 hours and embedded in paraffin. Sections sized $4 \mu \mathrm{m}$ were stained with Mayer's hematoxylin and eosin, elastin-van Gieson, $0.1 \%$ (w/v), Sirius red F3B (Gurr BDH, Poole, United Kingdom), and 2\% Alizarin Red (A5533; Sigma-Aldrich, St Louis, Mo). Additionally, sections were stained for macrophages (CD68) (1:200, ab22506; Abcam, Cambridge, United Kingdom) and alpha-smooth muscle actin ( $\alpha \mathrm{SMA}$ ) (1:32.000, A2547; Sigma-Aldrich). Sections were photographed (Nikon E800; Nikon, Tokyo, Japan) and analyzed with ImageJ software (National Institutes of Health and the Laboratory for Optical and Computational Instrumentation, University of Wisconsin, Madison, Wisc). ${ }^{9}$ Histological analysis is described in Appendix E1.

\section{Scanning Electron Microscopy}

Samples processing and imaging for scanning electron microscopy is described in Appendix E1. Leaflet and control surfaces were scanned and images were acquired at $50 \times, 100 \times, 400 \times$, and $800 \times$ magnification at the upper, mid, and lower region of the leaflet of both the ventricular and arterial side. The images were scored for endothelial cells, delamination, and vegetation on a scale from 0 to 3 by 2 investigators (KM and BS) in a blinded procedure, and then averaged. A score of 0 meant not present and a score of 3 meant clearly distinguishable and extensively present. For characterization of delamination and vegetation, images with a maximal magnification of $\sim 50 \times$ were scored. For endothelial cells, images with magnification of either $400 \times$ or $800 \times$ were used. Data analysis was performed on the average score per leaflet.

\section{Biochemical Analyses}

Biochemical analysis was performed on preimplant pSIS-ECM and at least 3 tissue samples from different regions of the valve per animal. The samples were digested overnight ( 16 hours) at $60^{\circ} \mathrm{C}$ in 300 to $400 \mu \mathrm{L}$ papain buffer (100 mM phosphate buffer, 5 mM L-cysteine hydrochloride (C1276; SigmaAldrich), $5 \mathrm{mM}$ ethylenediaminetetraacetic acid, and 125 to $140 \mu \mathrm{g} / \mathrm{mL}$ papain (P5306; Sigma-Aldrich). Samples were centrifuged and only the supernatant was used for measurements. The concentration of sulfated glycosaminoglycans (sGAG) was assessed based on the method of Farndale and colleagues ${ }^{10}$ DNA content was measured using Hoechst dye 33528 (14530; Sigma-Aldrich), ${ }^{11}$ and as an indicator for the amount of collagen fibers, the hydroxyproline content was measured according to the method of Huszar and colleagues. ${ }^{12}$

\section{Biomechanical Analysis}

Equibiaxial tests were performed on explanted samples of approximately $4 \mathrm{~mm} \times 4 \mathrm{~mm}$ from the midregion of the leaflets. Biomechanical analysis is further described in Appendix E1.

\section{Statistics}

Data were analyzed using SPSS (SPSS-IBM, Inc, Armonk, NY) and GraphPad (San Diego, Calif). Kruskal-Wallis test by ranks was 
1
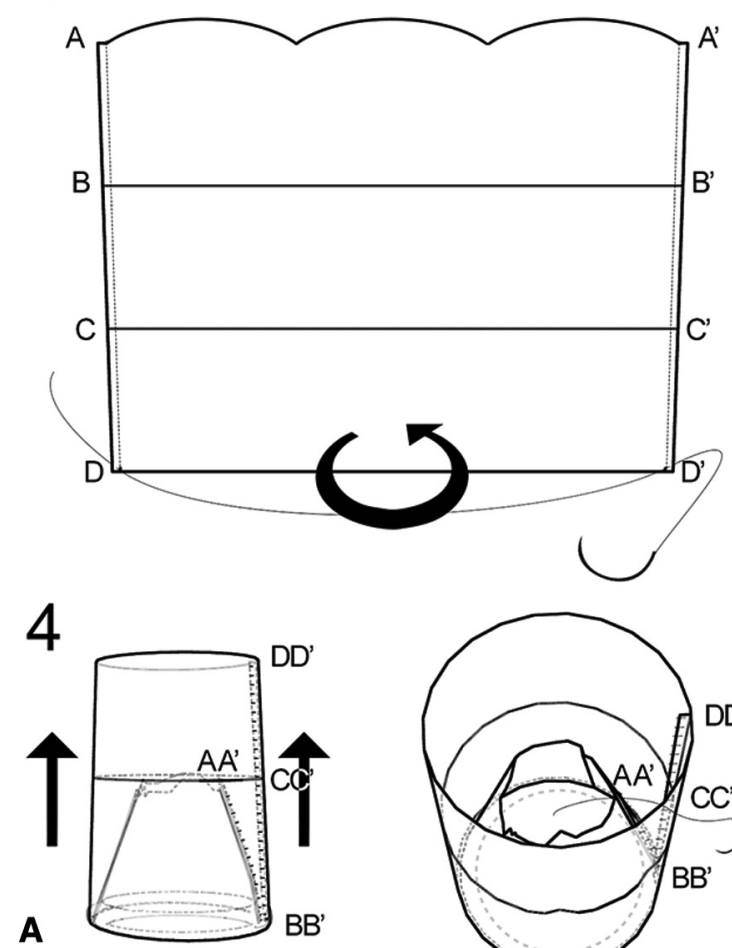

2
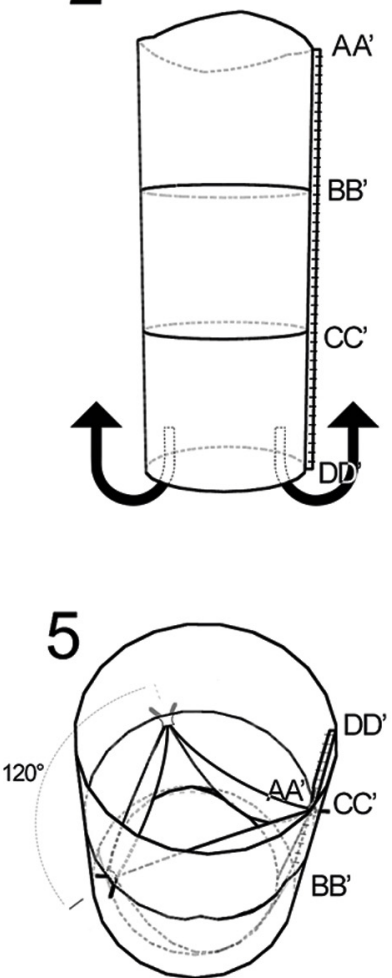

3

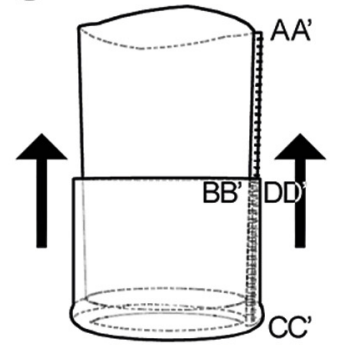

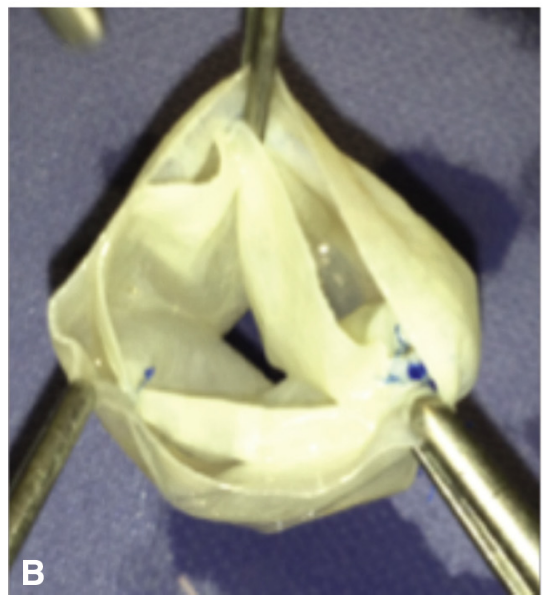
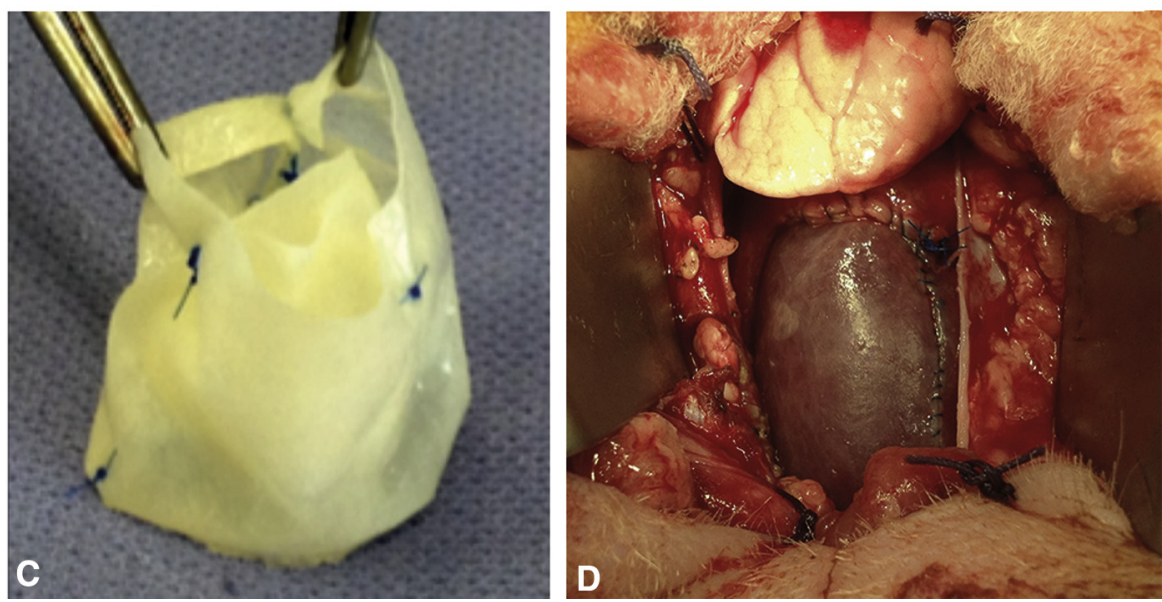

FIGURE 1. Three-dimensional valved conduit created out of flat trapezoid shaped piece of porcine small intestinal submucosa-extracellular matrix (pSISECM). A, pSIS-ECM sheet is cut to size having a larger length AA' versus DD'. Note the arched shape of the 3 free margins of the future leaflets. The width of the pSIS-ECM sheet at level $\mathrm{C}$ determines the diameter of the final conduit at the level of the top of the commissures (when folded and invaginated, either 19 or $23 \mathrm{~mm}$ ). The sheet is then rolled to form a cylinder and festinated along its length A'D'. The formed conduit is then invaginated until CC' is at the same height as AA', creating an inner- and outer tube. Free margins of individual leaflets become oversized, creating sufficient coaptation height. Stitches attaching the inner- to the outer-tube at the level of fused $\mathrm{A}^{\prime} \mathrm{C}^{\prime}$ every $120^{\circ}$ creates 3 equal leaflets supported by ECM patches. The distal part of the conduit is fashioned to correct conduit length at site of implantation. B and C, Valved conduit before implantation. D, Implanted valved conduit. (Design and creation with permission of P.F. Gründeman.)

performed to evaluate statistical significance between groups. Posthoc testing was done with Dunn's multiple comparisons test. MannWhitney tests were performed to compare medians of 2 groups. Interobserver agreement was analyzed using Cohen's kappa with linear weighting.

\section{RESULTS}

\section{Pulmonary Valve Replacement}

All valved conduits were successfully implanted with a median (interquartile range $[\mathrm{IQR}]$ ) bypass time of 
52 minutes (IQR, 37-67 minutes) in sheep and 44 minutes (IQR, 35-63 minutes) in lambs. Directly after implantation, a well-functioning pulmonary valved conduit was seen on epicardial echocardiography in all animals. Valve leaflets opened and closed with a large coaptation area without signs of stenosis or regurgitation. Seven animals died before planned follow-up (1 sheep and 1 lamb died within 1 month after implantation and 4 sheep and 1 lamb died during the second month after implantation) (Table 1). Most animals died due to congestive heart failure caused by pulmonary valve dysfunction; 1 animal showed signs of septic pulmonary embolism after 16 days. Five sheep $(1$ month $[\mathrm{n}=3]$, 3 months $[\mathrm{n}=1]$, and 6 months $[\mathrm{n}=1]$ ) and 8 lambs $(1$ month [n $=3$ ], 3 months $[\mathrm{n}=3]$, and 6 months $[\mathrm{n}=2])$ survived planned follow-up.

\section{pSIS-ECM Before Implantation}

Gross examination and (immuno)histochemistry of the conduit showed pliable leaflets with a large coaptation area before implantation. Presence of residual cellular DNA, collagen and anti- $\alpha$ SMA reactivity was seen (Figure 2, A and $I$, and Figure E1, $B$ and $C$ ). Measurable DNA content was confirmed using biochemical analysis (Figure 3,A). On scanning electron microscopy, a smooth and cell free surface with delamination of the layered collagen sheet was seen (Figure 4, $A$ and $B$ ). Biochemical analyses showed that the samples before implantation are collagen-rich with hydroxyproline concentrations in the range of native pulmonary valves and contained low amounts of sGAGs (Figure 3, B and $C$ ). The thickness of pSIS-ECM before implantation was $0.35 \pm 0.15 \mathrm{~mm}$ (Figure $3, E$ ). The tangent modulus for the radial direction $\left(3.8 \times 10^{4} \pm 1.9 \times 10^{4} \mathrm{kPa}\right)$ was not significantly different than for the circumferential direction $\left(3.4 \times 10^{4} \pm 2.0 \times 10^{4} \mathrm{kPa}\right)$ at a true strain of 0.3 (Figure $3, D$ ) and was highly variable. This led to an anisotropy index close to 0 (Figure 3, F).

\section{Animals That Survived Planned Follow-up}

One month. At 1 month after implantation, 1 out of 3 lambs had developed severe pulmonary valve stenosis

TABLE 1. Summary of valve performance in 10 sheep and 10 lambs implanted with a CorMatrix (CorMatrix Cardiovascular, Inc, Roswell, Ga) pulmonary valved conduit

\begin{tabular}{|c|c|c|c|c|c|c|}
\hline Follow-up (mo) & Animal & Premature death (d) & Cause of death & $\begin{array}{c}\text { Pmax gradient } \\
\text { (mm Hg) }\end{array}$ & PS grade* & PR grade \\
\hline & Sheep no. & & & & & \\
\hline \multirow[t]{3}{*}{1} & 2 & & & 3.5 & None & None \\
\hline & 4 & & & 8.9 & None & None \\
\hline & 7 & & & 9.8 & None & None \\
\hline \multirow[t]{3}{*}{3} & 1 & 51 & Heart failure & - & - & - \\
\hline & 3 & & & 8.6 & None & None \\
\hline & 13 & 60 & Endocarditis & - & - & - \\
\hline \multirow[t]{5}{*}{6} & 5 & & & 8.4 & None & Severe \\
\hline & 8 & 56 & Heart failure & - & - & - \\
\hline & 10 & 56 & Heart failure & - & - & - \\
\hline & 12 & 30 & Endocarditis & - & - & - \\
\hline & Lamb no. & & & & & \\
\hline \multirow[t]{3}{*}{1} & 3 & & & 9.7 & None & None \\
\hline & 5 & & & 66.5 & Severe & None \\
\hline & 11 & & & 7.2 & None & None \\
\hline \multirow[t]{3}{*}{3} & 1 & & & 79.6 & Severe & None \\
\hline & 4 & & & 50.7 & Moderate & None \\
\hline & 10 & & & 6.7 & None & None \\
\hline \multirow[t]{4}{*}{6} & 2 & 16 & $\begin{array}{c}\text { Endocarditis/ } \\
\text { pulmonary } \\
\text { embolism }\end{array}$ & - & - & - \\
\hline & 6 & & & 23.9 & Mild & None \\
\hline & 8 & & & 27.2 & Mild & None \\
\hline & 9 & 70 & Endocarditis & - & - & - \\
\hline
\end{tabular}



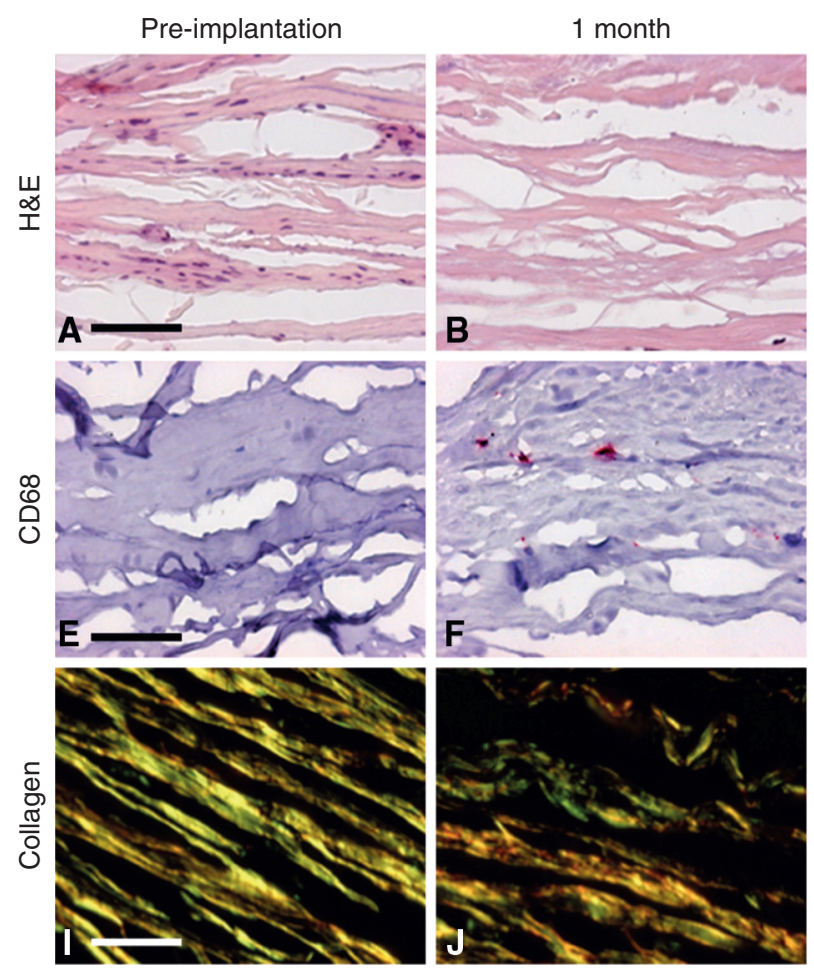

B
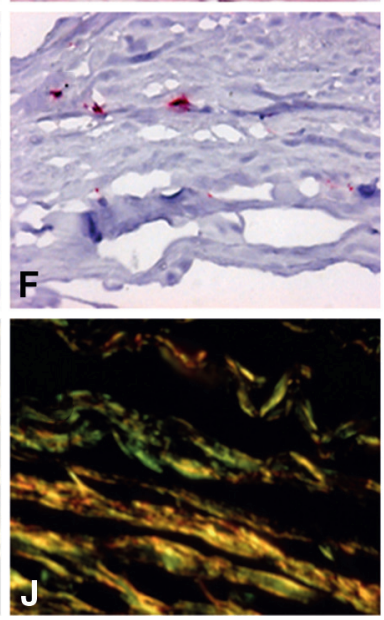

Cellularity - Lamb/Sheep

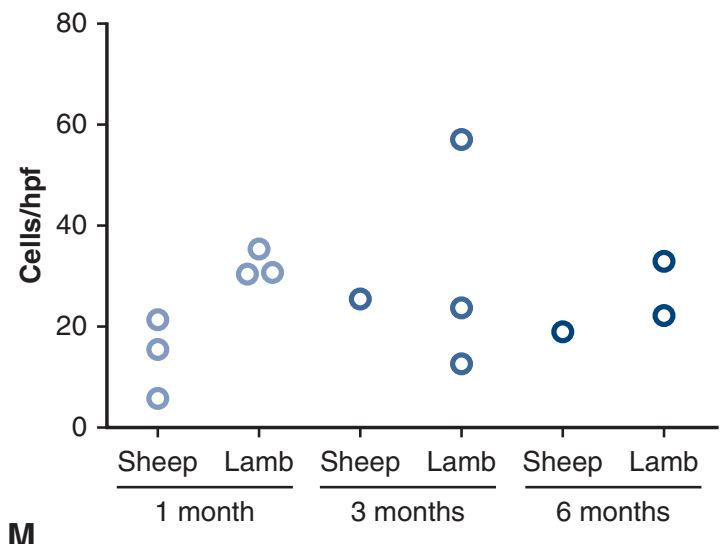

3 months
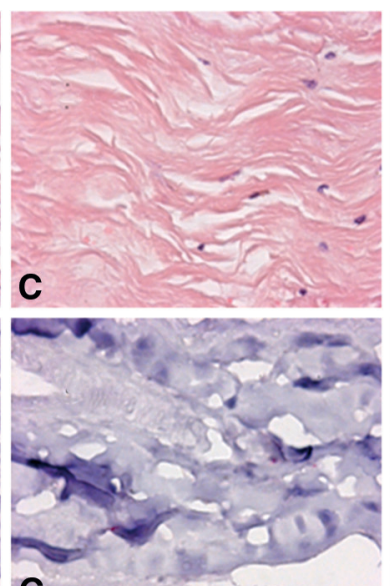

G

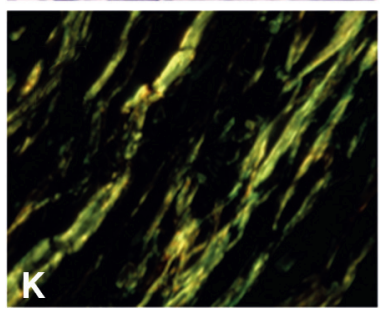

6 months
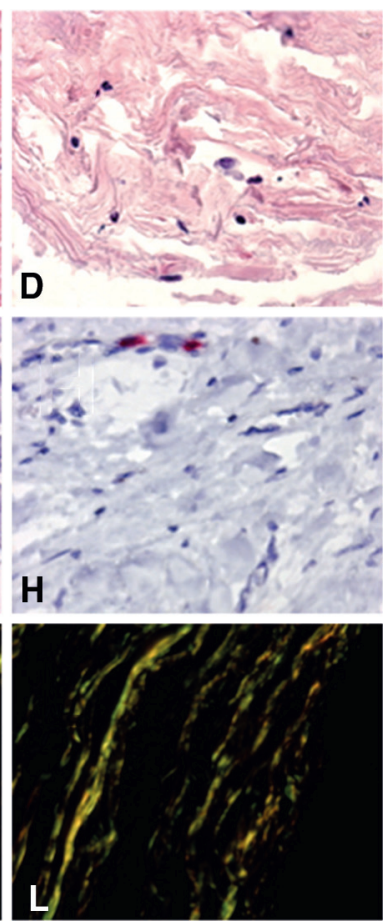

Cellularity valve- L/D

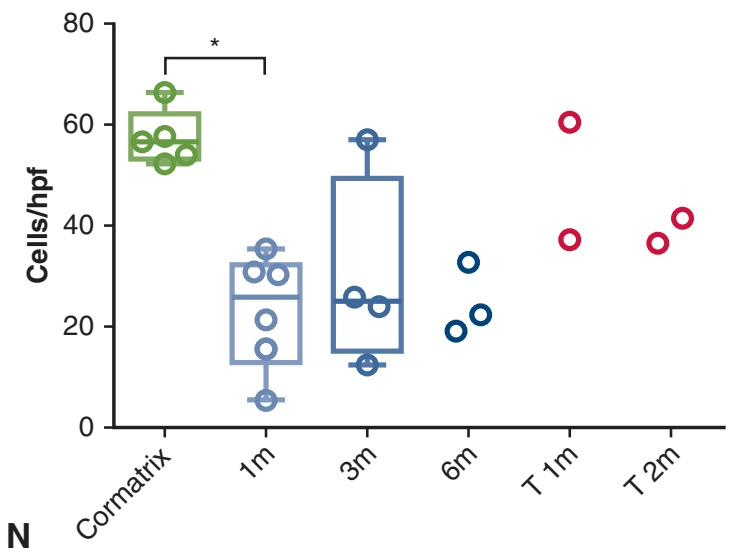

FIGURE 2. Histological changes of implanted decellularized extracellular matrix made from porcine small intestinal submucosa (pSIS-ECM). A, E, and I, pSIS-ECM before implantation. B, F, and J, At 1 month follow-up. C, G, and K, Three months follow-up. D, H, and L, Six months follow-up. A through D, Hematoxylin and eosin staining. E though H, CD68 for macrophages. I through L, Sirius red for collagen. M, Comparison between valve cellularity in lambs and sheep. N, Pooled comparison between animals that survived and animals that died $(L / D)$ before planned follow-up (analysis of variance, $P=.0204$ ). T 1 month and T 2 months are animals that died before follow-up. Scale bar represents $50 \mu \mathrm{m}$. Box plots represent median with interquartile ranges $(\mathrm{IQR}) \pm 1.5$ times IQR. $* P<.05$.

(PS) (Pmax, $66.5 \mathrm{~mm} \mathrm{Hg}$ ); the other surviving 2 lambs (median Pmax, 8.5 mm Hg [IQR, 7.2-9.7 mm Hg]) and 3 out of 3 sheep (Pmax, $8.9 \mathrm{~mm} \mathrm{Hg}[\mathrm{IQR}, 3.5-9.8 \mathrm{~mm} \mathrm{Hg}]$ ) were free from PS (Table 1).

Average leaflet thickness was $0.53 \pm 0.27 \mathrm{~mm}$ at 1 month $(\mathrm{n}=5)$. The stenosed valve was slightly thickened $(0.8 \mathrm{~mm})$ and showed signs of calcification at the base of the leaflets and increased levels of inflammatory cells. In sheep, 2 valves showed lightly thickened leaflets with a rough surface at 1 month. The remaining 3 valves in 2 lambs and 1 sheep, that were free of PS, showed pliable leaflets with a smooth surface (Figure 5, $A$ and $B$, and Figure 6, $A$ and $B$ ).

Inflammatory neutrophils and macrophages were seen lining the wall of the pSIS-ECM valved conduit; 
DNA

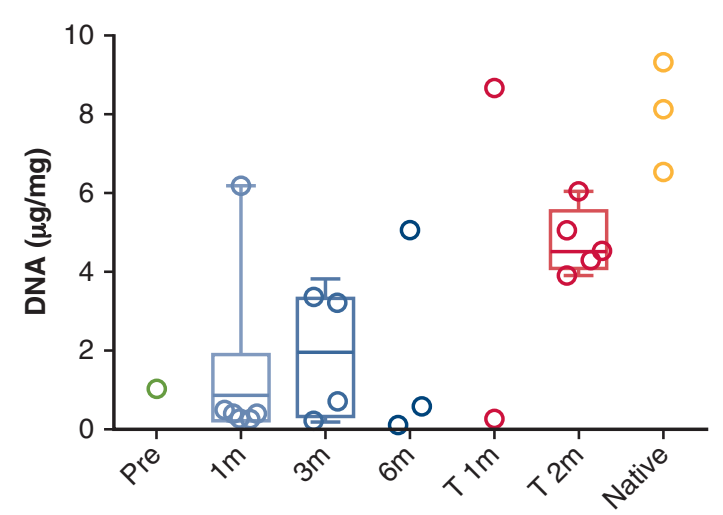

A

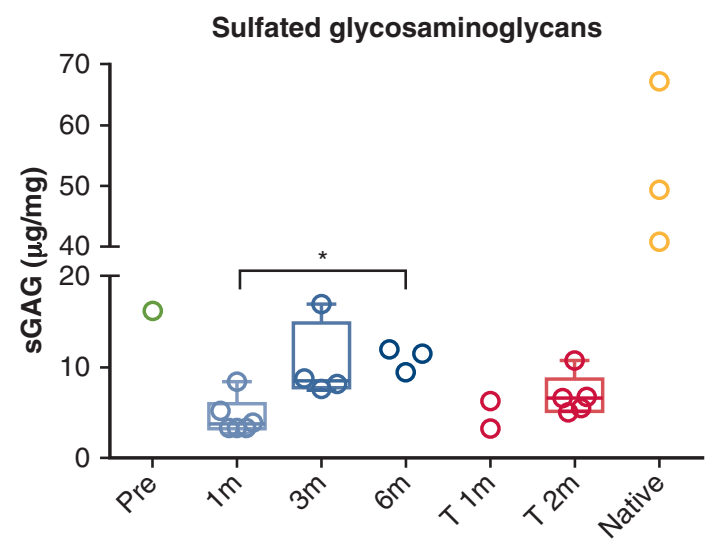

B

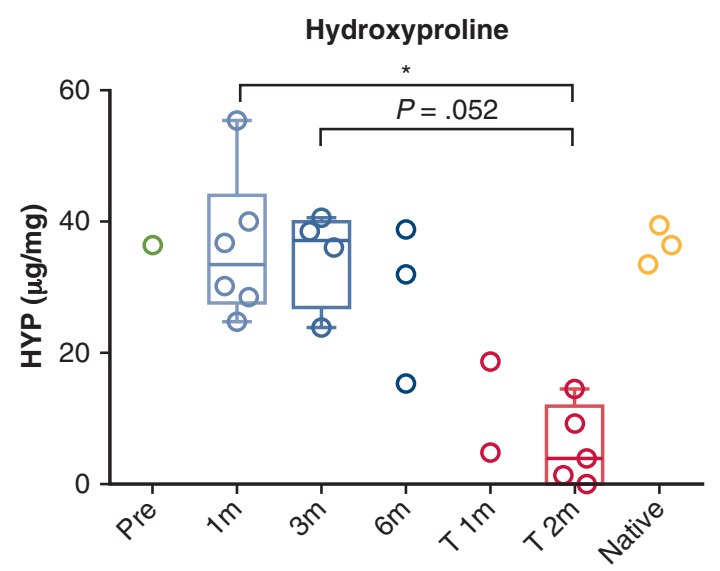

C

FIGURE 3. Biochemical and mechanical analysis of explanted valves. Concentrations. A, DNA (analysis of variance [ANOVA], $P=.25$ ). B, Sulfated glycosaminoglycans (ANOVA, $P=.016$ ). C, Hydroxyproline per group (ANOVA, $P=.011$ ). D, The tangent moduli as representation of stiffness (ANOVA, $P=.0081$ ). E, The thickness of the leaflets (ANOVA, $P=.0082) . \mathrm{F}$, The corresponding anisotropy indices for indication of higher stiffness in 1 direction over the other, indicating a preferred collagen in that direction (ANOVA, $P=.55$ ). T 1 month and T 2 months are animals that died before planned follow-up. Sheep and lambs are pooled per time point. Box plots represent median with interquartile ranges (IQR) $\pm 1.5 \times \mathrm{IQR}$. $* P<.05$. **P<.01.

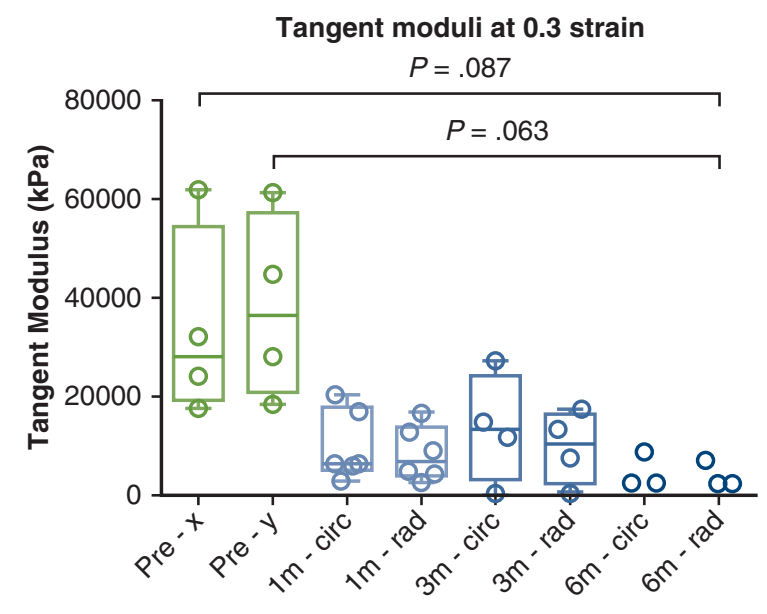

D

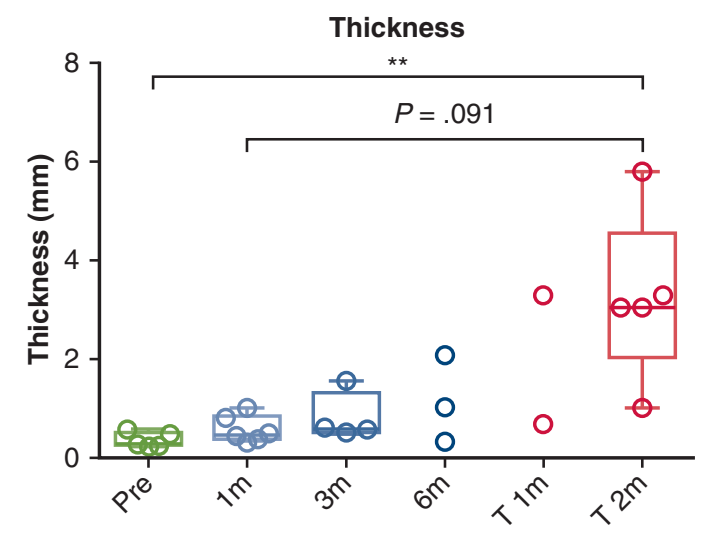

E

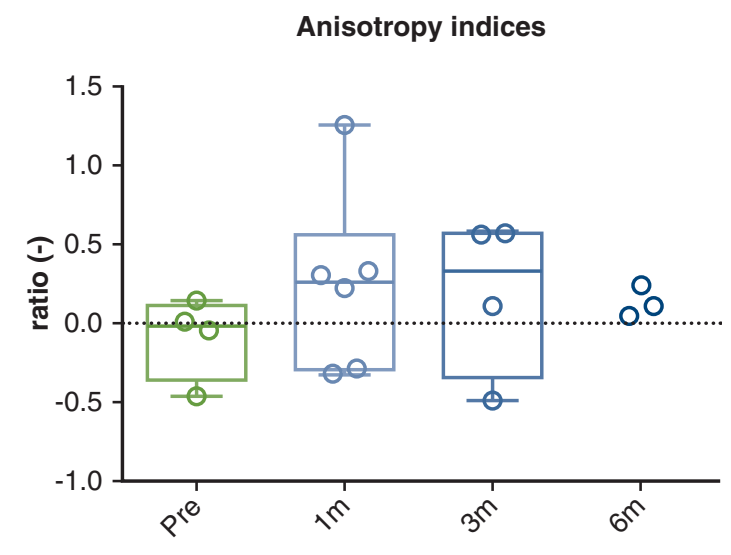



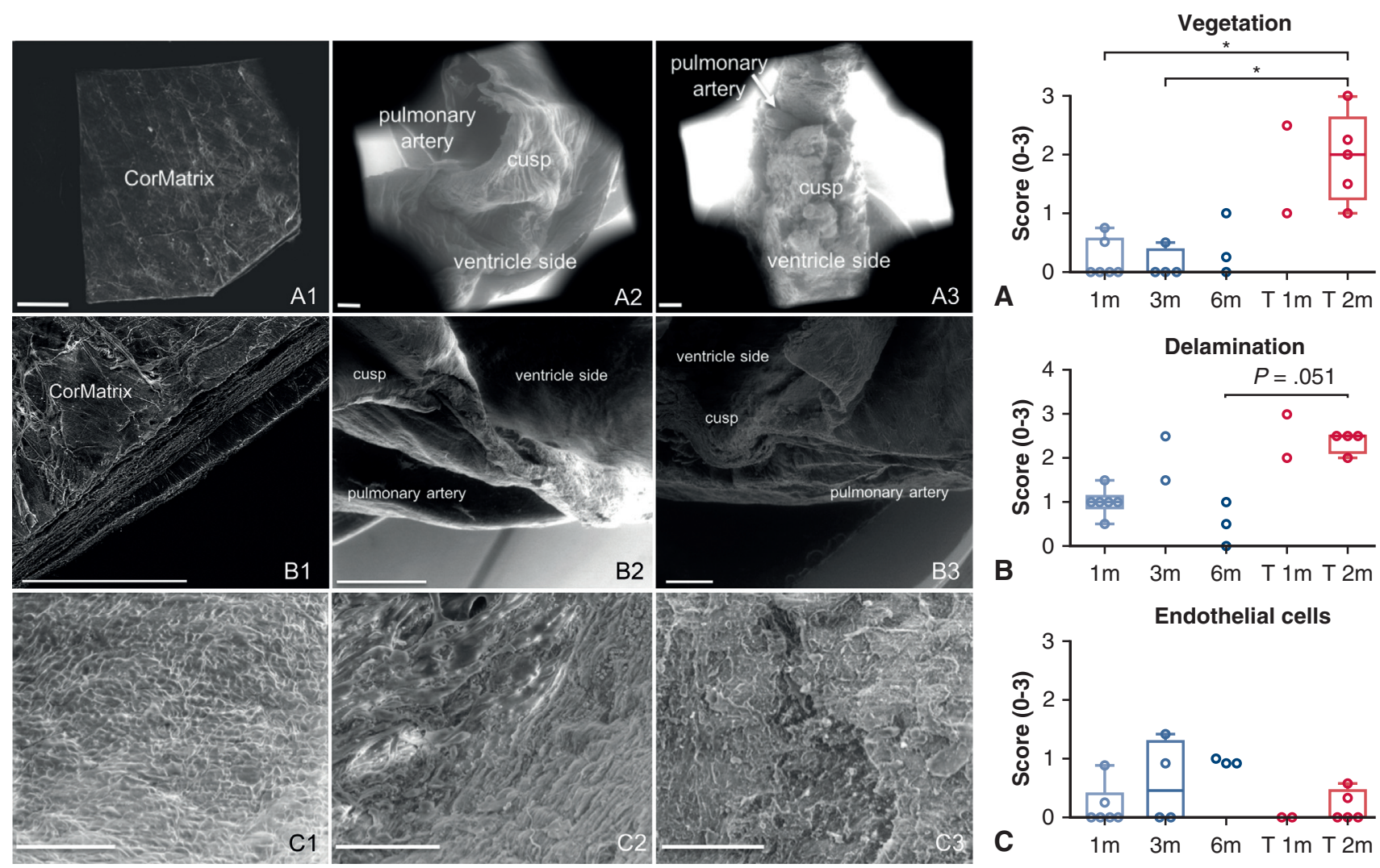

FIGURE 4. Surface appearance on scanning electron microscopy. Scores. A, Vegetation (analysis of variance [ANOVA] $P=.0076$ ). B, Delamination (ANOVA, $P=.0003$ ). C, Endothelialization of porcine small intestinal submucosa-ECM (pSIS-ECM) after explantation (ANOVA, $P=.0806$ ). Score $=0$ means not present and score $=3$ means clearly distinguishable and extensively present (eg, A1-3, B1-3, or C1-3). Before implantation (A1), the surface of pSIS-ECM is free of lumps, (A2) 3 months postimplantation a smooth surface is still visible, and (A3) the surface is covered with formed lumps in animals that died before planned follow-up. Delamination was noticeable before implantation (B1) and in animals that died before planned follow-up (B3), but less visible in the animals that survived planned follow-up (B2). A surface covered with endothelial cells (C1), partially covered areas show a transition zone (C2), and a lack of endothelial cells leaves a rough surface (C3). T 1 month and T 2 months are animals that died before planned follow-up. Sheep and lambs are pooled per time point. Scale bar represents $1 \mathrm{~mm}$ (A1-3 through B2 or 3), $500 \mu \mathrm{m}$ (B1) or 100 $\mu \mathrm{m}$ (C1-3). Box plots represent median with interquartile (IQR) ranges \pm 1.5 times IQR. Cohen's $\kappa=0.70$ for vegetation, 0.47 for delamination, and 1.00 for endothelialization. $* P<.05$.

inflammatory infiltration of leaflets was almost absent after 1 month. The clearly visible and numerous remnant nuclei present in the pSIS-ECM sheets before implantation, are cleared within the first month after implantation. The amount of cells infiltrating the sheets was significant lower compared with the number of cells in the neotissue lining the sheets; the amount of cells in the wall of the valved conduit was significantly higher than in the valves. The conduit wall, but not the leaflets, contained significant numbers of $\alpha$ SMA-positive cells (Figure E1, $B$ and $C$ ). Residual pSIS-ECM was apparent as a loose-appearing layered sheet similar to pSIS-ECM before implantation (Figure 2, A-D). An endothelial layer was virtually absent. Three months. At 3 months, 2 out of 3 lambs had developed moderate-severe PS (Pmax, $50.7 \mathrm{~mm} \mathrm{Hg}$ and $79.6 \mathrm{~mm} \mathrm{Hg}$ ). One lamb (Pmax, $6.7 \mathrm{~mm} \mathrm{Hg}$ ) and 1 sheep
(Pmax, $8.6 \mathrm{~mm} \mathrm{Hg}$ ) were free from valve dysfunction. These animals had pliable leaflets without thrombus or vegetation. Two out of 3 sheep died 1 month before planned follow-up due to heart failure. Leaflet thickness was $0.56 \pm 0.08 \mathrm{~mm}$ and at 3 months $(\mathrm{n}=2)$. Stenotic valves appeared thicker at $1.07 \pm 0.70 \mathrm{~mm}(\mathrm{n}=2)$.

A smooth surface and moderate delamination (Figure 4, $B$ ) was seen in all lambs and sheep. A few small lumps were formed on the surface of leaflets of stenosed valves (Figure 4, A). The stenosed valves showed signs of calcification at the base of the leaflets and increased levels of inflammatory cells. Next to macrophages and neutrophilic granulocytes, $\alpha$ SMA-positive cells were seen lining the wall of the conduit but were almost absent in the leaflets (Figure E1). An endothelial layer was virtually absent (Figure 4, C). 

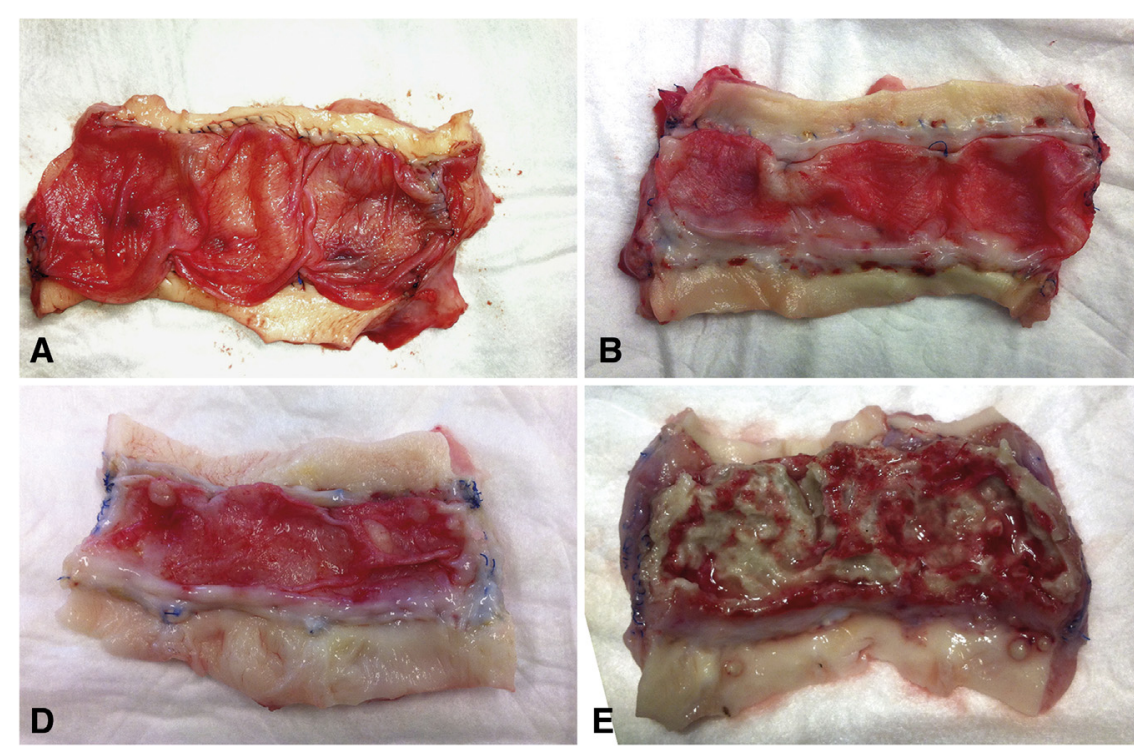
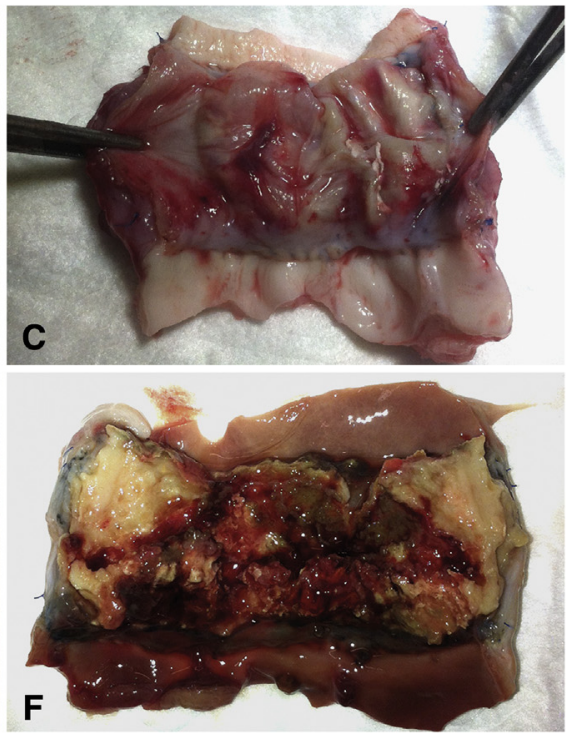

FIGURE 5. Macroscopy of explanted valves. A, One month postimplantation (sheep). B, 3 months postimplantation (sheep). C, One month after implantation (lamb). D, Six months after implantation (lamb). E and F, One and 2 months after implantation in animals that died before planned follow-up.

Six months. At 6 months, 2 out of 4 lambs and 1 out of 4 sheep survived. The surviving lambs had mild PS (Pmax, $23.9 \mathrm{~mm} \mathrm{Hg}$ and $27.2 \mathrm{~mm} \mathrm{Hg}$ ). The sheep that survived until 6 months was free of PS (Pmax, $8.4 \mathrm{~mm} \mathrm{Hg}$ ) but showed severe pulmonary regurgitation. Macroscopic examination of this conduit revealed that 2 valve leaflets had completely disappeared and the remaining leaflet was thickened. Microscopic examination showed calcific nodules in the valve of 1 lamb. The leaflets measured $1.14 \pm 0.89 \mathrm{~mm}$ thickness at 6 months $(\mathrm{n}=3)$.

The amount of cells in the leaflets did not increase over time (Figure 2, $N$ and $M$ ) and there was only limited coverage by endothelial cells after 6 months (Figure 4, $C$ ). New collagen formation was difficult to determine due to the collagen already present in the pSIS-ECM sheet before implantation (Figure 2, I-L). Hydroxyproline concentrations were comparable to preimplant pSIS-ECM (Figure 3,C). There was no elastin fiber formation and there were no signs of remodeling into tissue resembling a 3layered native heart valve. The sGAG concentration increased over time but never reached native valve levels. DNA concentrations were highly variable and did not significantly change over time or compared with pSISECM before implantation and was lower than in native valves (Figure 3, $A$ ).

The tangent modulus appeared decreased at all time points as compared with pSIS-ECM before implantation (Figure $3, D$ ). No significant difference in tangent modulus
$\underline{\mathbf{A}}$

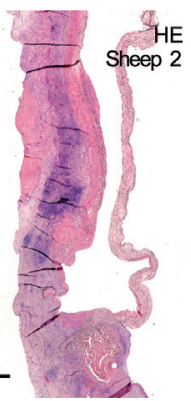

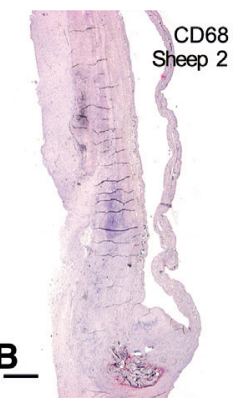
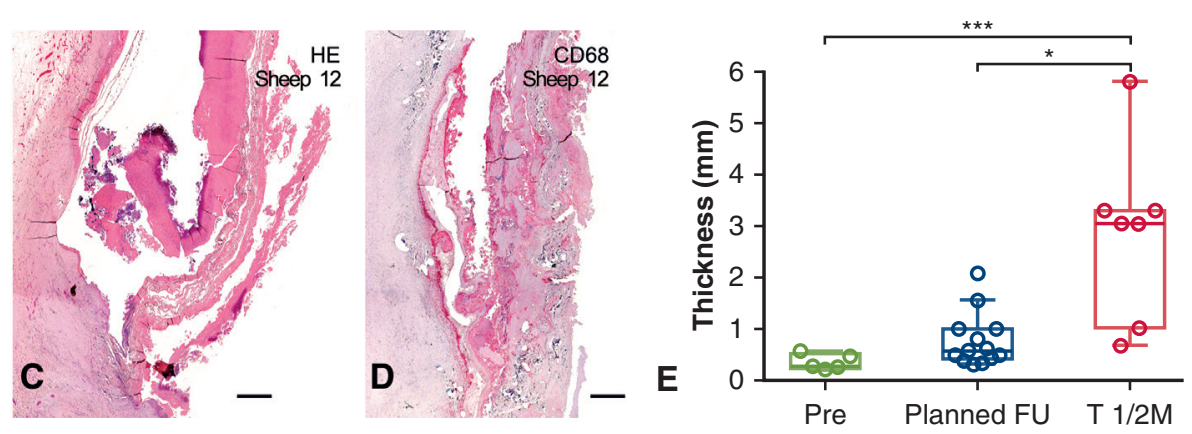

FIGURE 6. Histology of explanted valves. A and B, Sheep that survived until planned follow-up. C and D, Comparison with sheep that died before planned follow-up 1 month postimplantation. A and C, Hematoxylin and eosin staining. B and D, CD68. E, Thickness of the leaflets. T 1 or 2 months are animals that died before planned follow-up (analysis of variance, $P=.0007$ ). Sheep and lamb are pooled. Scale bar represents $1 \mathrm{~mm}$. Box plots represent median with interquartile ranges $(\mathrm{IQR}) \pm 1.5$ times IQR. $* P<.05$. $* * * P<.001$. 


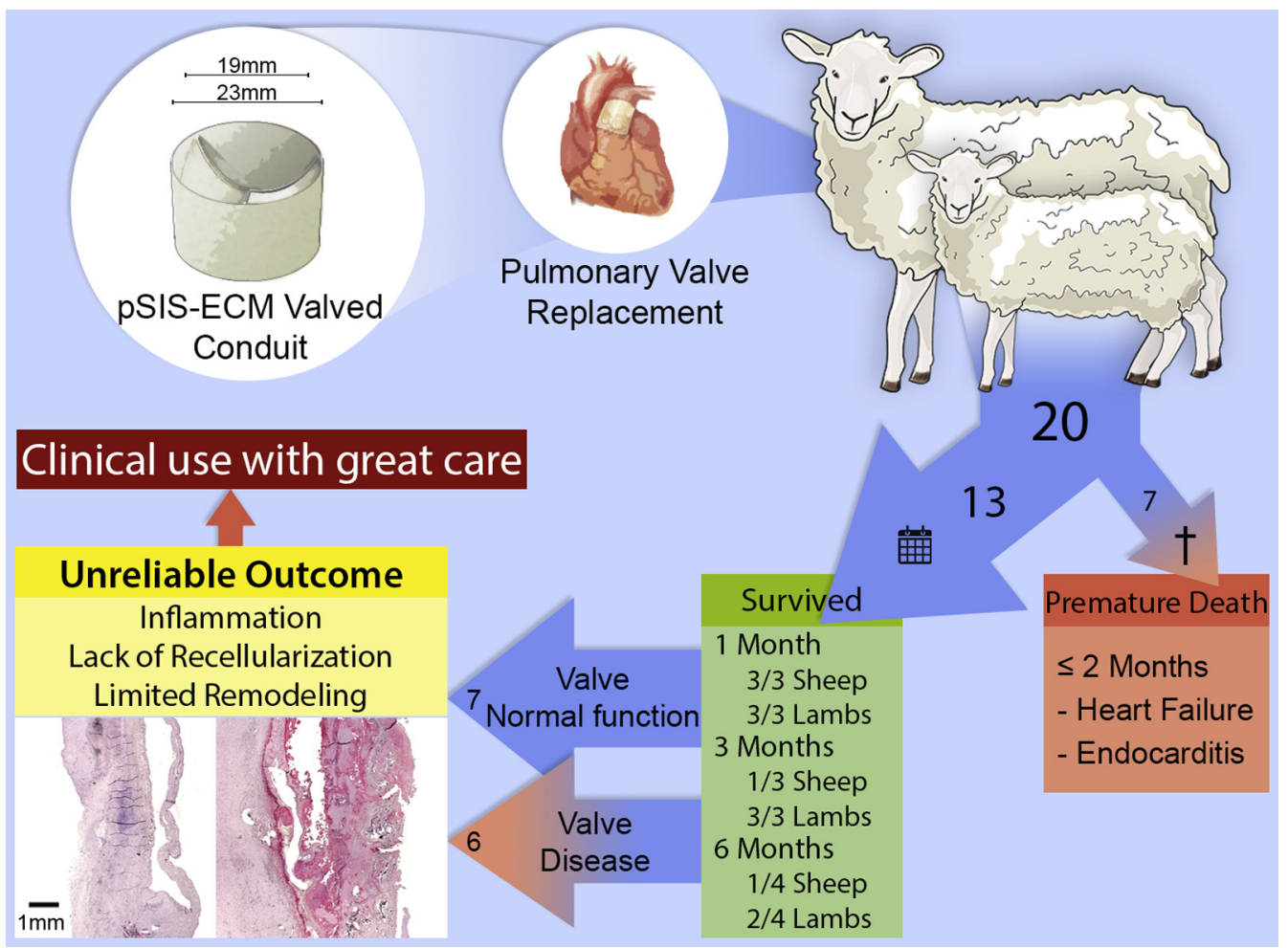

FIGURE 7. Unreliable outcome of porcine small intestinal submucosa extracellular matrix ( $p S I S-E C M$ ) implanted as a heart valved conduit. We evaluated pSIS-ECM as right-sided heart valved conduit in a xenogeneic sheep model. After implantation, 5 out of 10 of sheep and 2 out of 10 of lambs died within 2 months due to significant valve dysfunction. Valve failure was caused by an intense inflammatory response to the pSIS-ECM together with calcification and in some cases endocarditis. A well-functioning valve was seen in 4 out of 5 surviving sheep and 3 out of 8 surviving lambs. These valves however showed no signs of constructive tissue remodeling at 3 months after implantation. The use of CorMatrix (CoreMatrix Cardiovascular, Roswell, Ga) pSIS-ECM in heart valve surgery should be considered with great care because of unreliable outcomes in a xenogeneic setting.

between circumferential and radial direction was found and the average anisotropy index stayed close to 0 (Figure $3, F$ ).

\section{Animals That Died Before Planned Follow-up}

Seven animals (35\%) died before planned follow-up after a median of 56 days (IQR, 30-60 days) (Table 1). At the end of the study, valve function could only be assessed in animals that survived until planned follow-up.

Inspection of these valves showed thickened, rigid leaflets with vegetative growth (Figure 5, $E$ and $F$ ), significantly higher than in animals that survived planned follow-up at 1 or 3 months (Figure 3,A). Bacterial endocarditis was confirmed by Gram staining in 4 valves (Figure E2). An intense inflammatory reaction was seen in the pSIS-EMC sheet and lining the leaflet and the wall of the conduit. This response mainly consisted of neutrophilic granulocytes and CD68+ macrophages (Figure 6, $C$ and $D$ ). In the adjacent native tissue, macrophages and giant cells were seen in combination with lymphocytic infiltration, extending into the pSIS-ECM. Several calcific noduli were also observed in 2 sheep after 2 months.
Leaflets of animals that died before planned follow-up appeared more delaminated than those that survived; all were rated $\geq 2$ (Figure $4, B$ ). Minimal endothelialization was found in 2 animals (Figure 4,C). In the 5 other animals that died, no endothelial cells were observed.

A significant decrease in hydroxyproline was seen in valves of animals that died prematurely (Figure 3,C). The sGAG concentration was low and comparable to surviving animals (Figure 3, B). DNA concentrations in leaflets of 2 animals that died after 1 month varied largely and were more consistent in animals that died after 2 months (Figure 3, A). The amount of DNA appeared higher when compared with pSIS-ECM before implantation and of animals that survived until planned followup, but no significant difference was found between groups.

Due to thickening of the leaflets of the animals that died before planned follow-up, equibiaxial tensile testing could not be conducted. Leaflet thickness ranged from $1.99 \pm 1.85 \mathrm{~mm}(\mathrm{n}=2)$ at 1 month to $3.24 \pm 1.70 \mathrm{~mm}$ $(\mathrm{n}=5)$ at 2 months (Figure $3, E)$. 


\section{DISCUSSION}

Five sheep (50\%) and 8 lambs (80\%) implanted with pSIS-ECM valved conduits in the pulmonary position survived planned follow-up for up to 6 months. Of the surviving animals, 4 sheep and 3 lambs had a well functioning heart valve prosthesis for up to 3 months. Minimal signs of remodeling toward a 3-layered heart valve were seen, whereas the animals with valve dysfunction showed intense inflammatory reaction.

Since the first xenograft valve replacement in $1965,{ }^{13}$ the immune response to xenograft tissue has been problematic. All currently used bioprosthetic valves are exposed to glutaraldehyde to crosslink protein and reduce antigenicity. It is well known that glutaraldehyde cross-linking, although beneficial for mechanical and biological properties, can induce calcification. Therefore, some companies try to minimize its use; a product that completely avoids glutaraldehyde is CorMatrix pSIS-ECM. CorMatrix is a decellularized xenograft that is lyophilized and treated to be immunologically inert. pSIS-ECM sheets from CorMatrix are currently approved by the Food and Drug Administration (FDA) for use in the cardiovascular environment for pericardial reconstruction and repair, and as a patch for intracardiac tissue repair (ie, septal defects). pSIS-ECM has been shown to induce tissue-specific remodeling in the organ or tissue into which it is placed in various animal models, including heart valves. ${ }^{14-16}$ We unsuccessfully attempted to access the FDA documents of preclinical CorMatrix studies on which the FDA based its approval for clinical use. It would help doctors who consider using a new material if this (public) information could be accessible more easily.

In 2019, CorMatrix started an FDA feasibility study for its CorMatrix ECM tricuspid valve in a small population of pediatric and adult patients to replace a diseased tricuspid valve. ${ }^{17}$ First results will determine proof of principle and initial clinical safety. Estimated study completion date is December 2024. More than 30 other unique valve designs have been patented by the company over the past several years.

Probably the most important difference between CorMatrix with other xenogeneic valves and patches used in cardiac surgery is the absence of glutaraldehyde in the processing or storage. To the best of our knowledge there has been only 1 other nonglutaraldehyde-treated xenogeneic product on the market, the Synergraft (CryoLife Inc, Kennesaw, Ga). Synergraft produced porcine aortic composite grafts (model 500) or pulmonary roots (model 700) that were rendered cell-free through a proprietary process, and were not exposed to glutaraldehyde. In a study published in 2003, the Synergraft was used to reconstruct the right ventricular outflow tract in 4 pediatric patients, of whom 3 died and the fourth graft was explanted prophylactically. ${ }^{18}$ The valves elicited a strong inflammatory response leading to structural failure and rapid degeneration. Preimplant samples of the porcine Synergraft contained calcific nodules and revealed incomplete decellularization. These results illustrate the necessity of adequate antigen removal and stabilization in xenografts.

Since its introduction, a dozen experimental and clinical studies have investigated the use of CorMatrix pSIS-ECM in off-label heart valve repair and replacement. Initial research showed good valve function and progressive endothelialization and constructive remodeling in the short-term in porcine, ovine, and human atrioventricular and pulmonary valves. ${ }^{5,19,20}$ Miller and colleagues ${ }^{6}$ showed advanced remodeling in the pig pulmonary position with myofibroblast infiltration, endothelialization, and conduit growth. Despite this remodeling, all animals eventually developed significant valve dysfunction within 6 months. ${ }^{6}$

Incomplete resorption and disorganized degradation of pSIS-ECM accompanied by chronic inflammation, fibrosis, and calcification led to progressive mechanical and remodeling failure at 4 to 6 months in small preclinical studies in pig aortic valve. ${ }^{21,22}$ In line with these findings, the largest recent clinical studies on valve repair using CorMatrix have shown functional failure at short- and midterm follow-up with high reoperation rates. ${ }^{23-25}$ These explants were characterized by an inflammatory presence and absence of constructive remodeling and host-cell infiltration. This lack of histologic evidence that CorMatrix can act as a scaffold for reconstitution of native valve structures was underlined by several smaller clinical studies. ${ }^{7,26,27}$

Our findings in a sheep model of pulmonary valve replacement are similar to most recent reports of histologic findings in CorMatrix regarding valve failure: the presence of chronic inflammation and calcification, and a lack of constructive remodeling. We chose the sheep model because it is xenogeneic and represents the worst-case scenario for testing valve bioprosthetics in terms of calcification. ${ }^{28}$ It is also well known that reaction to bioprosthetic material is more severe in the pediatric population. CorMatrix has been used particularly in this patient group. Therefore, we implantated our valved conduits also in lambs.

Failure to remodel and premature dysfunction in xenogeneic tissue has been described as being multifactorial in nature. ${ }^{29}$ It appears to be a combination of tissue origin, tissue processing, host age, and the host's inflammatory response that leads to early valve deterioration. Other independent predictors of valve degeneration may be implant position and conduit design, both are likely related to stress distribution within the valve. We used a homemade valved conduit. Because there were 7 animals that showed a wellfunctioning valve months after implantation, we do not 
think that the design of the valved conduit has influenced the outcome of the present study.

Inflammation in CorMatrix in our sheep model may in part be explained by the xenogeneic nature of pSIS-ECM. Although CorMatrix is deemed a cell-free material, we found measurable amounts of residual DNA before implantation, confirming the findings of Naso and colleagues ${ }^{30}$ who observed an alarming amount of nucleic acid debris. On the other hand, most of the commercially available biological ECM materials contain at least some amount of DNA; however, this is typically present as small fragments and amounts that may be insufficient to elicit any adverse host immune response. ${ }^{16,31}$

Our conduits showed high susceptibility to infective endocarditis, with $20 \%$ of animals showing bacterial colonies in the explanted valves, leading to premature valve dysfunction and death within 2 months after implantation. One clinical study on the other hand showed CorMatrix to resist infection in a small number of patients with active endocarditis. ${ }^{19}$ Endocarditis after valve transplantation in sheep is not a rare occurrence, with reported numbers of $10 \%$ to $20 \%$ of animals in more than a dozen xenogeneic studies. ${ }^{32,33}$ Our group is very experienced in implanting pulmonary grafts in the ovine model and have not previously observed the high rate of endocarditis as seen here. $^{34}$

Our study has several limitations. Because 7 animals died before planned follow-up, statistical analysis was often impossible due to low number of animals, limiting our ability to draw conclusions in subgroups. We included no control group because the aim of the study was not to compare pSIS-ECM to other valve prostheses. Additionally, the length of follow-up was short; thus, we might have missed favorable remodeling that occurred after 6 months.

\section{CONCLUSIONS}

After implantation of a pSIS-ECM valved conduit, 5 out of 10 sheep and 2 out of 10 lambs died within 2 months due to significant valve dysfunction. Valve failure was caused by an intense inflammatory response to the pSIS-ECM together with calcification and in some cases endocarditis. A well-functioning valve was seen in 4 out of 5 surviving sheep and 3 out of 8 surviving lambs. These valves showed no signs of constructive tissue remodeling at 3 months after implantation (Figure 7). Possible cause of graft failure is likely multifactorial and may include the method of tissue processing and the host inflammatory response to graftspecific xenogeneic antigens (not masked by glutaraldehyde) and high mechanical stress. The unpredictable dichotomous outcome makes it challenging to predict whether current pSIS-ECM can be successfully applied in heart valve replacement or repair and its clinical use must be considered with great caution.

\section{Conflict of Interest Statement}

Dr Gründeman has a patent pending (BR112016025723 [A2] - 2018-06-19). Dr Bouten is a nonvoting share holder of Xeltis BV. All other authors have nothing to disclose with regard to commercial support.

The authors thank cardiovascular pathologists Aryan Vink and Allard van der Wal for providing expert insight.

\section{References}

1. Pibarot P, Dumesnil JG. Prosthetic heart valves: selection of the optimal prosthesis and long-term management. Circulation. 2009;119:1034-48.

2. Hoerstrup SP, Kadner A, Melnitchouk S, Trojan A, Eid K, Tracy J, et al. Tissue engineering of functional trileaflet heart valves from human marrow stromal cells. Circulation. 2002;106(12 Suppl 1):I143-50.

3. Bouten CV, Dankers PY, Driessen-Mol A, Pedron S, Brizard AM, Baaijens FP. Substrates for cardiovascular tissue engineering. Adv Drug Deliv Rev. 2011;63: 221-41.

4. Sacks MS, Gloeckner DC. Quantification of the fiber architecture and biaxial mechanical behavior of porcine intestinal submucosa. J Biomed Mater Res. 1999; 46:1-10.

5. Matheny RG, Hutchison ML, Dryden PE, Hiles MD, Shaar CJ. Porcine small intestine submucosa as a pulmonary valve leaflet substitute. J Heart Valve Dis 2000;9:769-74.

6. Miller JR, Henn MC, Lancaster TS, Lawrance CP, Schuessler RB, Shepard M, et al. Pulmonary valve replacement with small intestine submucosaextracellular matrix in a porcine model. World J Pediatr Congenit Heart Surg. 2016;7:475-83.

7. Zaidi AH, Nathan M, Emani S, Baird C, del Nido PJ, Gauvreau K, et al. Preliminary experience with porcine intestinal submucosa (CorMatrix) for valve reconstruction in congenital heart disease: histologic evaluation of explanted valves. $J$ Thorac Cardiovasc Surg. 2014;148:2216-24.

8. Gilbert CL, Gnanapragasam J, Benhaggen R, Novick WM. Novel use of extracellular matrix graft for creation of pulmonary valved conduit. World J Pediatr Congenit Heart Surg. 2011;2:495-501.

9. Schneider CA, Rasband WS, Eliceiri KW. NIH Image to Image J: 25 years of image analysis. Nat Methods. 2012;9:671-5.

10. Farndale RW, Buttle DJ, Barrett AJ. Improved quantitation and discrimination of sulphated glycosaminoglycans by use of dimethylmethylene blue. Biochim Biophys Acta. 1986;883:173-7.

11. Cesarone CF, Bolognesi B, Santi L. Improved microfluorometric DNA determination in biological material using 33258 Hoechst. Anal Biochem. 1979;100: 188-97.

12. Huszar G, Maiocco J, Naftolin F. Monitoring of collagen and collagen fragments in chromatography of protein mixtures. Anal Biochem. 1980;105:424-9.

13. Binet JP, Carpentier A, Langlois J, Duran D, Colvez P. [Implantation of heterogenic valves in the treatment of aortic cardiopathies]. C R Acad Sci Hebd Seances Acad Sci D. 1965;261:5733-4.

14. Badylak S, Meurling S, Chen M, Spievack A, Simmons-Byrd A. Resorbable bioscaffold for esophageal repair in a dog model. J Pediatr Surg. 2000;35: 1097-103.

15. Ruiz CE, Iemura M, Medie S, Varga P, Van Alstine WG, Mack S, et al. Transcatheter placement of a low-profile biodegradable pulmonary valve made of small in testinal submucosa: a long-term study in a swine model. J Thorac Cardiovasc Surg. 2005;130:477-84.

16. Badylak SF, Gilbert TW. Immune response to biologic scaffold materials. Semin Immunol. 2008;20:109-16.

17. CorMatrix ECM tricuspid valve replacement. Available at: https://clinicaltrials gov/ct2/show/NCT02397668. Accessed June 5, 2019.

18. Simon P, Kasimir MT, Seebacher G, Weigel G, Ullrich R, Salzer-Muhar U, et al. Early failure of the tissue engineered porcine heart valve SYNERGRAFT in pediatric patients. Eur J Cardiothorac Surg. 2003;23:1002-6.

19. Gerdisch MW, Shea RJ, Barron MD. Clinical experience with CorMatrix extracellular matrix in the surgical treatment of mitral valve disease. $J$ Thorac Cardiovasc Surg. 2014;148:1370-8.

20. Fallon AM, Goodchild TT, Cox JL, Matheny RG. In vivo remodeling potential of a novel bioprosthetic tricuspid valve in an ovine model. J Thorac Cardiovasc Surg. 2014;148:333-40. 
21. Mosala Nezhad Z, Poncelet A, Fervaille C, de Kerchove L, Gianello P. Experimental aortic valve cusp extension with CorMatrix in a porcine model. Thorac Cardiovasc Surg. 2017;65:206-10.

22. Mosala Nezhad Z, Poncelet A, de Kerchove L, Fervaille C, Banse X, Bollen X, et al. CorMatrix valved conduit in a porcine model: long-term remodelling and biomechanical characterization. Interact Cardiovasc Thorac Surg. 2017;24:90-8.

23. Padalino MA, Castaldi B, Fedrigo M, Gallo M, Zucchetta F, Vida VL, et al. Porcine intestinal submucosa (CorMatrix) for semilunar valve repair in children: a word of caution after midterm results. Semin Thorac Cardiovasc Surg. 2016;28:436-45.

24. Padalino MA, Quarti A, Angeli E, Frigo AC, Vida VL, Pozzi M, et al. Early and mid-term clinical experience with extracellular matrix scaffold for congenital cardiac and vascular reconstructive surgery: a multicentric Italian study. Interact Cardiovasc Thorac Surg. 2015;21:40-9.

25. Kelley TM Jr, Kashem M, Wang H, McCarthy J, Carroll ND, Moser GW, et al. Anterior leaflet augmentation with CorMatrix porcine extracellular matrix in twenty-five patients: unexpected patch failures and histologic analysis. Ann Thorac Surg. 2017;103:114-20.

26. Hofmann M, Schmiady MO, Burkhardt BE, Dave HH, Hubler M, Kretschmar O, et al. Congenital aortic valve repair using CorMatrix: a histologic evaluation. Xenotransplantation. 2017;24(6).

27. Woo JS, Fishbein MC, Reemtsen B. Histologic examination of decellularized porcine intestinal submucosa extracellular matrix (CorMatrix) in pediatric congenital heart surgery. Cardiovasc Pathol. 2016;25:12-7.

28. Ali ML, Kumar SP, Bjornstad K, Duran CM. The sheep as an animal model for heart valve research. Cardiovasc Surg. 1996;4:543-9.
29. Flameng W, Meuris B, Yperman J, De Visscher G, Herijgers P, Verbeken E. Factors influencing calcification of cardiac bioprostheses in adolescent sheep. $J$ Thorac Cardiovasc Surg. 2006;132:89-98.

30. Naso F, Aguiari P, Iop L, Spina M, Gerosa G. Biocompatibility evaluation criteria for novel xenograft materials: distribution and quantification of remnant nucleic acid and alpha-gal epitope. J Stem Cell Res Ther. 2013; 3(S6-009).

31. Gilbert TW, Freund JM, Badylak SF. Quantification of DNA in biologic scaffold materials. J Surg Res. 2009;152:135-9.

32. Flameng W, Hermans H, E Verbeken E, Meuris B. A randomized assessment of an advanced tissue preservation technology in the juvenile sheep model. J Thorac Cardiovasc Surg. 2015;149:340-5.

33. Pettenazzo E, Thiene G, Gatti AM, Pasquino E, Talenti E, Noera G, et al. Is the tricuspid position suitable for testing replacement bioprosthetic valves in the sheep model? J Heart Valve Dis. 2001;10:513-9.

34. Kluin J, Talacua H, Smits AI, Emmert MY, Brugmans MC, Fioretta ES, et al. In situ heart valve tissue engineering using a bioresorbable elastomeric implantfrom material design to 12 months follow-up in sheep. Biomaterials. 2017; 125:101-17.

Key Words: decellularized small intestinal submucosa, pulmonary valve replacement, heart valve surgery, animal model, xenograft 


\section{APPENDIX E1. METHODS Pulmonary Valve Replacement}

Animals were placed on cardiopulmonary bypass via the left carotid artery and jugular vein. A left-sided anterolateral thoracotomy was performed in the third or fourth intercostal space. On the beating heart the pulmonary artery was transected at the level of the commissures and the native pulmonary valve leaflets were excised. The valved conduit was implanted as interposition graft in the pulmonary artery. The distal and proximal anastomosis was made using running sutures. After weaning from extracorporeal circulation, an epicardial echocardiography was obtained to assess valve function and the diameter in the middle of the valved conduit and at the proximal and distal suture line during systole. A second epicardial echocardiogram was made just before each animal was put to death. Animals received lifelong Ascal (80 mg/d orally; Ratiopharm, Ulm, Germany). Animals also received 1 daily dose of depomycine $1 \mathrm{~mL} /$ $20 \mathrm{~kg}$ postoperative intramuscular injection.

\section{(Immuno)histochemistry and Histologic Quantification}

Two investigators (JWR and HT), who were blinded for age and time point of explantation, conducted analysis of cellularity (total amount of cells per high power field, $40 \times$ objective lens) and average area of collagen or immunopositive cells, and then averaged. For cellularity, 15 areas in the wall of the valved conduit were analyzed. At 5 levels, the adventitial, middle, and luminal side of the graft wall were analyzed. In the leaflet, 5 levels were analyzed, from tip to base at pulmonary, middle and ventricular side of the leaflets. For collagen and immunopositive cells, the average positive area was determined by threshold at 18 high powered fields on 9 areas in the wall of the conduit and 9 in the leaflets. All observations were made in a blinded fashion by 2 observers and results were averaged.

For Gram staining, $4 \mu \mathrm{m}$ sections were deparaffinized, rehydrated, and subsequently stained with crystal violet solution and mordanted with Lugol's iodine solution. After differentiation in absolute acetone, sections were stained with dilute carbol fuchsin solution and differentiated. Next, sections were counterstained with light green SF (C.I. 42095; Gurr BDH, Poole, United Kingdom) and dehydrated in acetone-xylene and xylene. Gram-negative bacteria color red, whereas gram-positive bacteria are blue/violet and collagen is green.

\section{Scanning Electron Microscopy}

Samples were fixed in $2.5 \%$ glutaraldehyde and dehydrated in a graded ethanol series, starting from $50 \%$ to $100 \%$ in $5 \%$ to $20 \%$ increments. The ethanol was then allowed to evaporate, and samples were gold-sputtered for visualization. Scanning electron microscopy (Inspect F; FEI Company, Eindhoven, The Netherlands) images were obtained with a secondary electron detector at low vacuum mode, a voltage of $10 \mathrm{kV}$ and a spot size of 4.0.

\section{Biomechanical Analysis}

First, the sample thickness was measured with a digital microscope (VHX-500FE; Keyence, Woodcliff Lake, NJ). Thereafter, samples were mounted in a Biotester system (Cell scale, Waterloo, Ontario, Canada) between Biorakes with $0.7 \mathrm{~mm}$ thin space (World Precision Instruments, Berlin, Germany). The samples were equibiaxial preconditioned in five cycles of 0.30 strain at a strain rate of 1.0 per minute. Every strain cycle also included a recovery period at the same strain rate and a rest period of $3 \times$ the stretch time. From the last cycle, the last measurement was used for data analyses. The obtained force-strain curve was translated to a stress-strain curve, in which a sixth order polynomial curve was fitted through each individual data set in both radial and circumferential direction. Tissue stiffness was represented by the tangent moduli in radial $\left(\mathrm{T}_{\mathrm{r}}\right)$ and circumferential $\left(\mathrm{T}_{\mathrm{c}}\right)$ direction and calculated as the slope from the tangent to the fitted polynomial curve at the maximum strain of 0.30 . To assess collagen fiber orientation, the anisotropy index $\left(\mathrm{A}_{\mathrm{i}}\right)$ was defined as:

$$
A_{i}=\frac{T c}{T r}-1
$$

So for $\mathrm{Ai}>0$ the predominant fiber orientation is circumferential, for $\mathrm{Ai}<0$ the predominant fiber orientation is radial, and for $\mathrm{Ai}=0$ there is no preferred direction.

\section{RESULTS}

\section{Valve Function}

In lambs, the diameter of the valved conduit during systole seemed to increase over time at the distal suture line (9.6 $\pm 3.5 \mathrm{~mm}$ at 1 month, $11.8 \pm 5.6 \mathrm{~mm}$ at 3 months, and $16.5 \pm 0.7 \mathrm{~mm}$ at 6 months). In the middle of the valved conduit, the diameter seemed to shrink initially and increased at 6 months $(12.2 \pm 7.3 \mathrm{~mm}$ at 1 month, $9.5 \pm 4.8 \mathrm{~mm}$ at 3 months, and $17 \pm 0.0 \mathrm{~mm}$ at 6 months). At the proximal suture line, the diameter did not increase $(11.7 \pm 4.5 \mathrm{~mm}$ at 1 month, $11 \pm 5 \mathrm{~mm}$ at 3 months, and $13.5 \pm 2.1 \mathrm{~mm}$ at 6 months). In sheep the diameter did not increase in the middle of the valved conduit $(17 \pm 7 \mathrm{~mm}$ at 1 months, $19 \mathrm{~mm}$ at 3 months, and $19 \mathrm{~mm}$ at 6 months), nor at the proximal or distal suture line (proximal suture line; $18.3 \pm 6.7 \mathrm{~mm}$ at 1 month, $16 \mathrm{~mm}$ at 3 months, and $17 \mathrm{~mm}$ at 6 months. Diameter distal suture line $19 \pm 6 \mathrm{~mm}$ at 1 month, $18 \mathrm{~mm}$ at 3 months, and 18 at 6 months). 

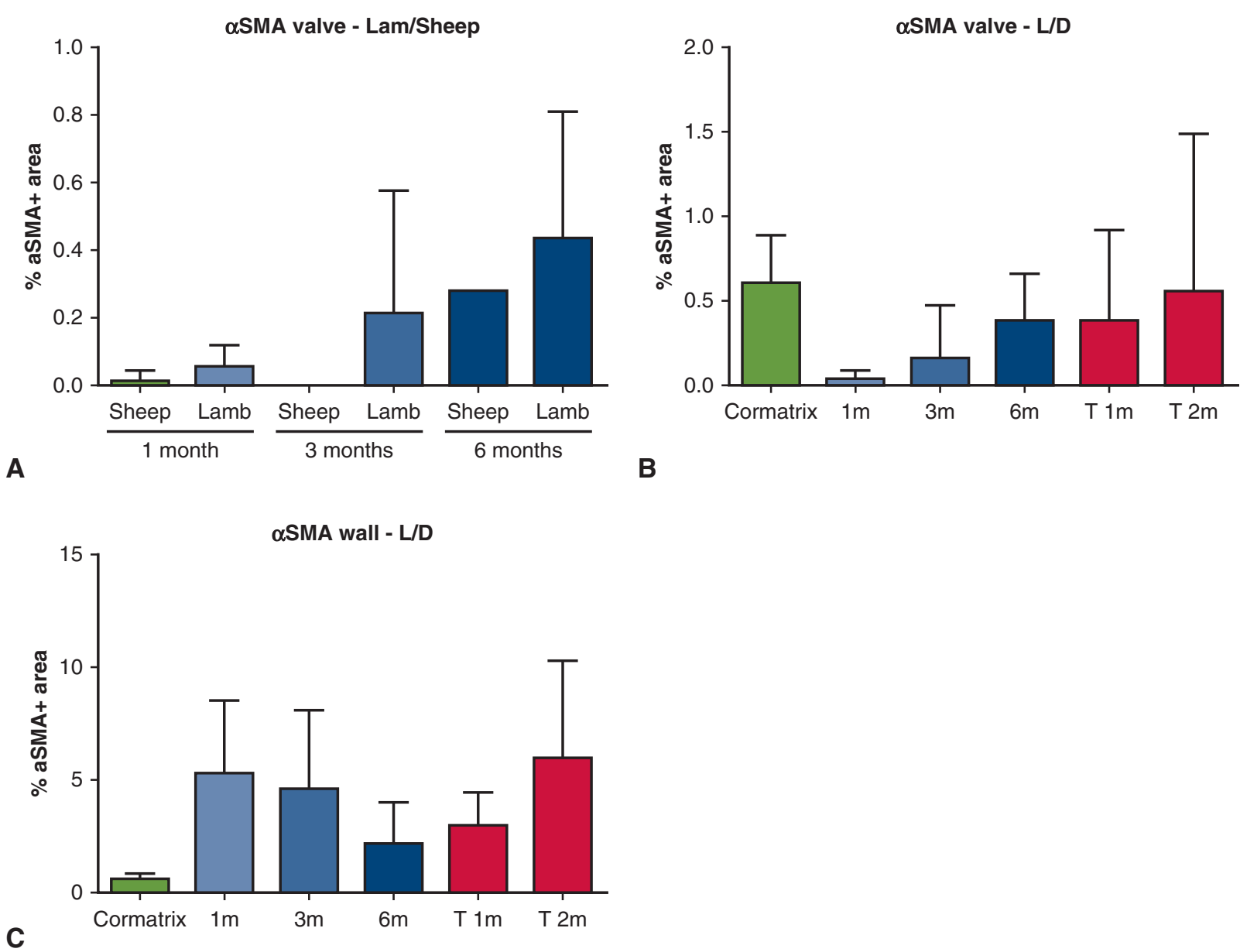

FIGURE E1. Conduit alpha-smooth muscle actin $(\alpha S M A)$ expression. A, Comparison between valve $\alpha$ SMA expression in lambs and sheep. Comparison between animals who survived and animals who died $(L / D)$ before planned follow-up. B, Valve. C, Conduit wall. T 1 month and T 2 months are animals that died before follow-up due to valve failure. 


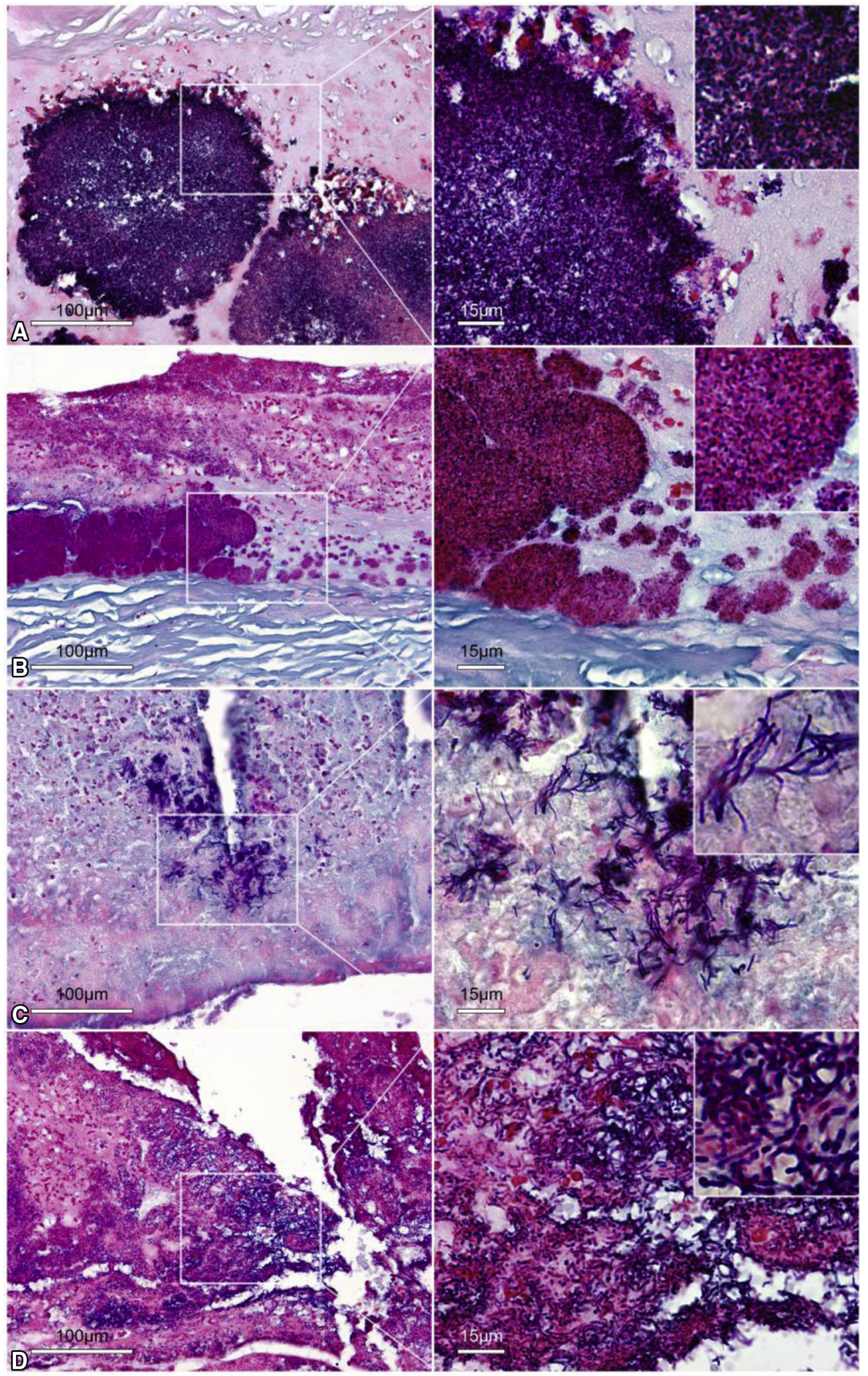

FIGURE E2. Gram stain examples on animals that died prematurely. A, Large colonies of gram-positive cocci in fibrin vegetation surrounded by phagocytosing macrophages. B, Mixed colonies of gram-positive and gram-negative cocci on the border of porcine small intestinal submucosa extracellular matrix (pSIS-ECM). C, Gram-positive rods in fibrin. D, Gram-positive and gram-negative cocci. 